\title{
INVASIVE NON-NATIVE Solidago SPECIES IN LATVIA: EXPANSION HISTORY AND CURRENT DISTRIBUTION
}

\author{
Agnese Priede \\ Faculty of Geography and Earth Sciences, University of Latvia, Alberta 10, Riga, LV-1006, LATVIA \\ E-mail: agnesepriede@ hotmail.com
}

Communicated by Oḷǵerts Nikodemus

\begin{abstract}
Two non-native Solidago L. species of North-American origin are aggressive plant invaders in most of Europe. Solidago canadensis occurs frequently in most of temperate Europe, while S. gigantea lags behind in north and east Europe. For the first time the distribution and history of expansion of both Solidago species in Latvia were studied and reviewed in maps. The distribution data were gathered mainly in field surveys (2004-2007); other data sources include herbarium materials, literature and unpublished data. Both the widespread S. canadensis and rare S. gigantea are well adapted to a wide range of habitats mostly occurring in human-disturbed habitats in the vicinity of settlements and transportation routes. Over the last century, the dispersal success of goldenrods had been greatly facilitated by land use changes, human alteration of ecosystems, and development of transportation networks.
\end{abstract}

Key words: distribution, invasive species, Solidago gigantea, Solidago canadensis.

\section{INTRODUCTION}

The spread of non-native invasive species is a significant part of today's changing biota facilitated by human alterations in most of ecosystems. Deliberate and accidental species introductions into other continents have greatly benefited from increased human mobility and development of transportation networks (Hodkinson and Thompson, 1997; Weber, 1998; Henderson et al., 2006). The interdisciplinary field of invasion biology concentrates on many aspects of invasion process, including studies of range expansions that helps to understand the reasons of success and failures of invaders and potential for their future spread (Weber, 1998).

Canadian goldenrod Solidago canadensis L. and late goldenrod S. gigantea Ait. are considered as "black list" invasive species in most of temperate Europe. Both goldenrod species are native to North America and introduced into Europe as garden ornamentals in the 17th century (Harnett and Bazzaz, 1983; Weber, 1998; 2000). In its native range, $S$. canadensis occur in tall grass prairies and light forest edges. Often it is a weedy component of vegetation on abandoned pastures and unmanaged roadsides as well as in human-disturbed habitats in urban areas and settlements (Walck et al., 1999). It develops relatively stable secondary communities in old fields (Harnett and Bazzaz, 1983). S. gigantea is more common on wetlands, river banks, fens and wet depressions (Jakobs et al., 2004; Weber and Jakobs, 2005).
Both S. canadensis and S. gigantea are perennial herbs. They are considered as highly variable species, and their taxonomic status is not unambiguous. Both species belong to the genus Solidago which comprises about 130 taxa (mostly native to North America). In their native range in North America several different taxonomic subunits have been recognized within the $S$. canadensis complex which are granted species status by some authors (Weber, 2000). In a strict sense, the complex species $S$. canadensis in Europe is called S. altissima (Harnet and Bazzaz, 1983; Gassman and Weber, 2005). In Europe, S. gigantea refers to a whole complex of various $S$. gigantea species (Weber and Jakobs, 2005). S. gigantea can be easily distinguished from the congener species $S$. canadensis by its longer rhizomes, brownish white pappus, glabrous stems and the denser inflorescence architecture (Weber and Jakobs, 2005).

Both goldenrods spread both by vegetative and sexual reproduction. In short distances, usually within the populations and in the vicinity of established stands, they spread by rhizomes and shoots (Dancza and Botta-Dukát, 2001; Gassman and Weber, 2005). Due to human alteration rhizomes can be transported far from the initial source by natural (flowing water, animals) or human created agents (e.g. road reconstruction, removing soil or garden throw-outs). Despite the high regeneration ability by rhizomes, the species spreads mainly by seeds, which can be disseminated by wind in long distances. Seeds are small, produced in large numbers (an individual shoot produces up to 10000 seeds) and have long pappi which facilitates wind dispersion. 
(Dancza and Botta-Dukát, 2001; Gassman and Weber, 2005).

Several comprehensive studies on the introduced goldenrod species and their expansion in Europe were published by Weber (1998; 2000; 2001), Weber and Schmid (1998), Jakobs et al. (2004) and Weber and Jakobs (2005). They mentioned a continuous increase in number of species records and expansion of the geographical range. Guzikowa and Maycock (1986) studied the spread of three introduced goldenrod species in Poland. Similarly to other studies, their results show an exponential expansion of both non-native goldenrods in Europe.

S. canadensis was brought into the territory of Latvia in the beginning of 19th century when the Baltic German merchants established the first plant nurseries in the Baltic region, the former part of the Russian Empire. Initially, the seed material was obtained from Western Europe. Plant nurseries in Riga began to distribute seedlings of goldenrods at the beginning of the 19th century. In 1805 and 1817 , the first plant catalogues were issued by J. H. Zigra, the owner of the first ornamental plant nursery in Riga, where 17 Solidago species and/or varieties were mentioned, including S. canadensis (Ievin,a, 1964). Later, seeds and planting material were distributed and sold to other regions of the Russian Empire. Within the territory of Latvia, the oldest known herbarium materials of $S$. canadensis were collected in 1906 by K. R. Kupffer and P. Lakschewitz (RIG). By the middle of the 20th century, there were still little data on the species distribution. In 1946, the species was mentioned by Bickis and Rasiņš (1946) and in 1959 by Pētersone (1959) as a naturalised garden ornamental in several localities throughout Latvia. In 1988, Tabaka (Табака и др., 1988) noted that $S$. canadensis occurred occasionally in weed-laden sites, in ruderal habitats, on road and railway verges and in various urban habitats.

Although S. canadensis is widely recognized as one of the most aggressive invasive species, there is little knowledge on its actual distribution in Latvia. Evidently, S. gigantea lags behind with lower invasion rates and scanty distribution. Up to now, no comprehensive reviews and distribution maps of non-native goldenrods in Latvia had been published. This study for the first time summarises all data available on the distribution and dynamics of $S$. canadensis and $S$. gigantea in Latvia. The results are aimed to fill the gaps in the knowledge on the distribution and ecology of $S$. canadensis and S. gigantea in a part of Eastern Europe.

\section{DATA AND METHODS}

All known records of $S$. canadensis and S. gigantean, including herbarium materials, literature sources (Bickis un Rasiňš, 1946); Pētersone, 1959; Anonīms, 2004; 2006; 2007), floristic data obtained from personal communication were used. Herbarium data from the collections of the Institute of Biology, University of Latvia (LATV) and the Faculty of Biology, University of Latvia (RIG) were summarised.
In 2004-2007, most of the territory of Latvia was systematically surveyed by the author of this paper. The field survey method was based on a regular quadrate grid of $10 \times 10 \mathrm{~km}$ covering mostly potentially invaded areas. Most of localities were detected by moving along roads and surroundings of settlements in various types of habitats. All noticed localities of both Solidago species were recorded with their geographical coordinates and in a data base. Invaded habitat types and visual assessment of abundance in each locality were noted. In data analysis, habitat types were generalised and unified into groups such as ruderal habitats (e.g. waste grounds, disturbed sites, and weed-laden sites), grasslands/meadows, fallows, roadsides, railways etc.

GIS software ESRI ArcGis 9.0 was used in mapping. A distribution data base containing north and east coordinates (LKS-92 coordinate system) for each locality were transformed into shapefiles storing all localities as point features. Maps of the current distribution of both Solidago species were prepared in a regular $5 \times 5 \mathrm{~km}$ quadrate grid. All points falling into a cell were selected and enclosed into the quadrate. Presence of species (one or more localities) within a quadrate was marked by a black square.

Chronologies based on herbarium records and grid-based mapping is a widely used biogeographical approach (Pyšek and Prach, 1995; Mack, 2000) mainly used for areas such as countries and regions, where a certain generalisation is acceptable. It is suitable also in cases when the data are approximate, namely, taken from sources with different degree accuracy or not obtained using the same method. Quadrate maps showing presence and absence are an appropriate tool in monitoring the change in distribution. After a repeated field survey the number of cells invaded can be easily compared with the previous results.

\section{RESULTS}

Inventory of herbarium materials shows that there are very few data on the species in the early 20th century and two decades after World War II. Up to 1950, only two herbarium specimens of $S$. canadensis were collected, both in Koknese (RIG). In the 1970s, systematic floristic surveys began throughout Latvia, nevertheless, very few herbarium specimen were obtained (five in the period from 1950 to 1970, and 24 from 1971 to 1990). Most of localities (347) were recorded during the last few years after 2005. In spite of the insufficient data over the last decades, it is likely that there was a lag phase between the arrival of the species and its naturalisation. It is likely that the initial phase of expansion over the boundaries of cultivation throughout Latvia began around 1950, while $S$. gigantea became naturalised considerably later by the end of the 1980 s. For the first time in Latvia, S. gigantea specimens were collected in 1989 in Rìga (LATV), in 1995 in Kemeri and Rìga, and the others after 2002 (LATV). Currently 17 localities are known in various locations in Rīga and in a few sites in Jūrmala and Jelgava. 
Recent data and field study clearly show that nowadays $S$. canadensis is a common non-native species in Latvia (Fig. 1). Apparently, the distribution pattern of S. canadensis is related to the road network, certain land use types and density of human-settlements. The majority of the localities occur in cities and adjacent areas, and along arterial roads and railways. Often the species invades vast areas in the vicinity of cities and towns, while there are considerably fewer records from sparsely inhabited remote areas. Comparatively few records of the species were collected in forest-dominated and on less intensive farmland-dominated areas, e.g. the Vidzeme Upland and northern part of Kurzeme.

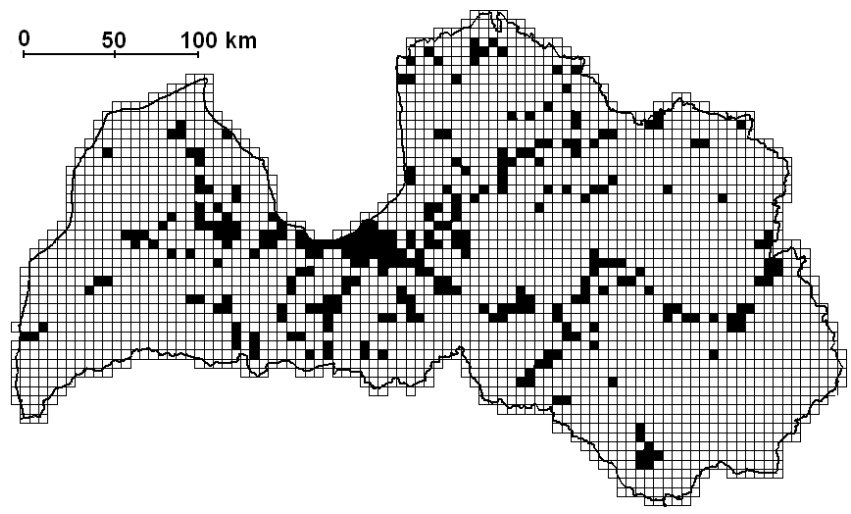

Fig. 1. Distribution of $S$. canadensis in Latvia in a regular $5 \times 5 \mathrm{~km}$ grid. Presence is marked by a black square.

There is no information on the arrival of S. gigantea in Latvia that might have been earlier than the first collected herbarium records. Its current distribution is confined to a small territory within the capital and surrounding towns (Fig. 2). In a few sites, it has invaded large areas, where it forms large monodominant patches or mixed stands with other tall herbs and grasses such as S. canadensis, Artemisia vulgaris, Phragmites australis and Calamagrostis epigeios.

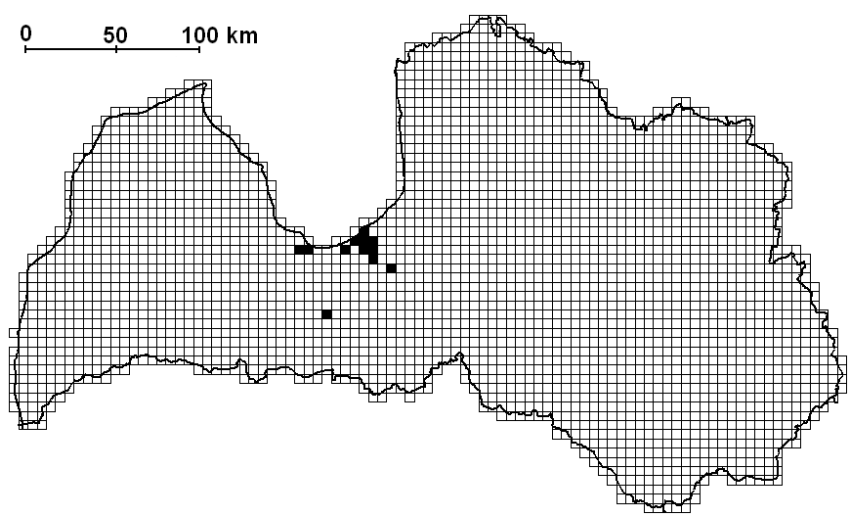

Fig. 2. Distribution of $S$. gigantea in Latvia in a regular $5 \times 5 \mathrm{~km}$ grid.

Invaded habitat complexes. $S$. canadensis occurs on roadsides, fallows, railway verges, in grasslands, ruderal sites (weed-laden sites, waste dumps, and urban areas). The other localities were found in quarries, shrubs, reed communities and moist depressions dominated by ruderal tall herbs, river banks, forest edges, or in the vicinity of ceme-

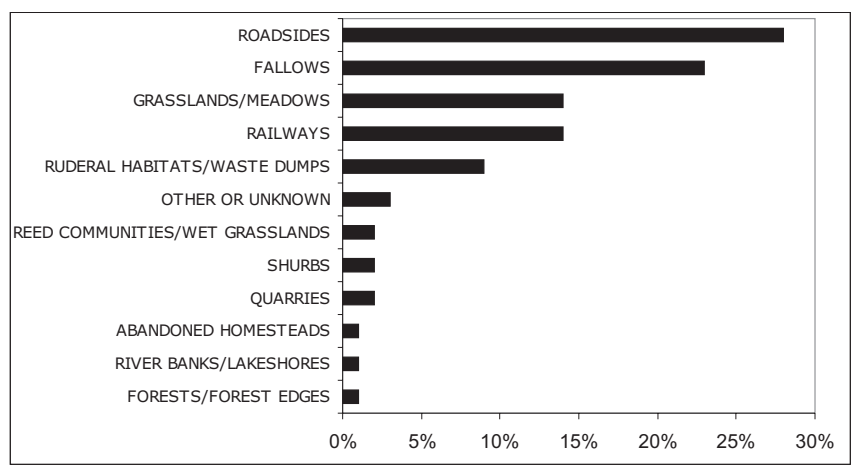

Fig. 3. Habitats invaded by $S$. canadensis in Latvia.

teries (Fig. 3). It has been rarely found in semi-natural and natural meadows (on wet riverine floodland meadow, several localities in abandoned calcareous Molinia caerulea dominated and Sesleria caerulea dominated meadows). Often it is not possible to distinguish a certain habitat type on the same location, since $S$. canadensis is well adapted to relatively wide range of ecological conditions and is found in various habitats within the same locality.

Similar to $S$. canadensis, the congener $S$. gigantea seems to be a successful invader of various environmental conditions from dry sandy dunes to drained peat soils and wet habitats. Recently it was recorded in Jelgava on the floodland of the River Lielupe

In Latvia, both species occur in ruderal Artemisietea communities in disturbed ruderal habitats, in MolionioArrhenatheretea communities in grasslands and PhragmitiMagnocaricetea communities in wetlands. The species composition is variable. Both species can grow in species-poor communities on nutrient-poor soils, moderately rich plant communities in grasslands and fallows, ruderal tall herb communities on roadsides and waste dumps and humid reed communities in disturbed wet habitats.

\section{DISCUSSION}

It is likely that the simultaneous introduction in a large part of Europe in the middle of the 19th century was the main factor for the rapid spread of goldenrods outside cultivation. Due to easy cultivation and adaptability to local climate conditions goldenrod became popular as garden ornamentals, initially cultivated mainly in botanical gardens, later in manors, parks, city greeneries and private gardens. Its popularity in gardens and parks and easy dispersal ability ensured rapid naturalisation, successful establishment and spreading outside cultivation.

Evidently, cities and towns served as the main dispersal centres for radial spread of $S$. canadensis. Similarly in rural areas, manors and adjacent parks could have been the dispersal centres, while later the ornamentals were introduced in the farm gardens.

The results of the study show that often roads and railways are important migration corridors. Thus, it is not surprising 
that most of localities occur along transportation routes as secondary establishment sites. Later the species can spread across the adjacent habitats. Generally, development of transportation and construction of roads greatly facilitated the spreading of the species. To a great extent, the success of goldenrods was based on its seed dispersal qualities (disseminated by wind, seeds are equipped with pappus), germination characteristics and capacity to establish persistent seed bank. It can survive competitive pressure of other species by means of its clonal growth (Cornelius 1990). Seed dissemination by wind helps to establish into new localities further away from parent plants. Seeds may be attached to vehicles, transported by air movements caused by transportation. The situation in Latvia shows that semi-natural open land use types such as fallows and grasslands are often suitable for quick establishment of vast goldenrod populations, not only in the vicinity of cities and towns, but also in remote areas several kilometres away from any human settlements. Abandoned lands, poorly managed areas in the vicinity of roads and railways, and heavily disturbed habitats are the most susceptible to Solidago invasion.

Similarly to many other introduced non-natives, distribution and spread of both Solidago species are closely related to historical and socio-economic aspects. From the point of view of land use history in Latvia over the last 50-60 years, we can assume that there had been aspects facilitating, and, on the other hand, confining the 2nd part of 20th century did not allow the spread of the species in grasslands and fallows. Most of the fields were abandoned in the 1990s, thus providing suitable habitats for vast goldenrod populations. During the last two decades most of the lots in cities and towns were abandoned, allowing uncontrolled spread of recently cultivated and managed species into the neighbouring semi-natural habitats. Many other factors including uncontrolled waste dumping, expansion of ruderalised urban and suburban areas, presence of unmown road and railway verges promoted invasion of non-native invasive species. Processes of both land use intensification, e.g. establishment of allotments in the vicinity of cities, towns and railway verges and the following recent land abandonment have significantly facilitated the spread of non-native goldenrods, particularly S. canadensis.

There are considerable potential sources of error and reconstructing the spread of non-native Solidago species in Latvia. The early phases of spread are based more on assumptions and guesses than historical records. Similar to other invasive escaped garden ornamentals, it is difficult to draw a distinction between the early records and herbarium materials taken from gardens and those from naturalised populations. The early records often lack any information on habitat types. Over the last century, the botanical field surveys did not cover the whole territory of Latvia with regular frequency. After World War II, little attention was paid to non-native species and they were rarely included in the flora lists of particular areas, thus the distribution maps presented in this paper show the current situation but do not allow tracking the history of spread over the last century. In Eu- rope several studies concerning the dynamics of non-native plant species have been performed by analysing the herbarium records. For example, Lacey (1957) studied the spread of the agricultural Galinsoga species; Pyšek and Prach (1995) studied the spread of Impatiens glandulifera in the Czech Republic, Mandák et al. (2004) studied the history of the invasion of Reynoutria species in the Czech Republic; B. Tokarska-Guzik (2003) analysed the expansion of neophyte species in Poland using a similar approach. Similarly to other invasive species in Central Europe, the spread of Solidago species in Latvia might have been gradual and perhaps exponential in a certain phase. However, due to data limitations it is not possible to estimate the invasion phases quantitatively as it has been done in some other European countries.

Similar to several other North-American species in Europe, being a weedy component in the native range is a prerequisite for becoming invasive also in the introduced range (Forman, 2003). Similar to its native range, in Europe S. canadensis invades mainly dry, disturbed habitats, while $S$. gigantea prefers mainly wet habitats, although in the introduced range it has adapted to a wider range of conditions than in the native range by occurring also on drier soils (Weber and Jakobs, 2005; Güsewell et al., 2006) and in some countries being a more successful invader than $S$. canadensis (Dancza and Botta-Dukát, 2001). In Latvia, the distribution and habitat preferences of $S$. canadensis suggest that the species tolerates both dry and moist soil conditions in disturbed and semi-natural habitats. Currently, it is far more widespread than $S$. gigantea. Nevertheless, $S$. gigantea is tending to expand its range and increase the competitive pressure on $S$. canadensis in moist and wet habitats (Jakobs et al., 2004). Observations in several sites invaded by $S$. gigantea in Latvia, e.g. Zakusala and Lucavsala in Riga suggest that $S$. gigantea is likely to outcompete the comparatively earlier introduced $S$. canadensis.

Field observations in Latvia prove that, similar to Central Europe (e.g. Weber and Jakobs, 2005), both species can form monodominant stands and grow in mixed tall herb stands with other invasive species such as Impatiens glandulifera and Helianthus tuberosus. In Latvia, commonly $S$. canadensis grows in scattered patches, while dense monodominant stands are rarely observed (Riga, Koknese) suggesting that in some cases $S$. gigantea may benefit from the ability to build dense monospecific stands. Both in their native and introduced ranges, non-native Solidago species occur mainly in ruderal plant communities; in Europe they occur in Artemisietea, MolionioArrhenatheretea and Agropyretea communities in ruderal habitats and Convolvulion and Salicion communities in riparian communities in the inundation areas (Lohmeyer and Sukopp, 1992; Müller and Okuda, 1998). The main threats for local plant communities may occur if $S$. canadensis establishes in natural or semi-natural meadows, wetlands or nutrient-poor natural grasslands. The expansion of non-native goldenrods and ongoing overgrowing by both native and non-native tall herbs causes homogenisation of local 
plant communities, extinction of typical species compositions of various grassland types and perhaps rare, ecologically narrow, rare plant species. Overgrowing of grasslands and fallows by tall herbs also visually changes the traditional landscape.

Although the results based on the grid mapping approach presented in this study might be related to some limitations and perhaps do not reveal the entire spatial distribution of both non-native goldenrods, this was the first attempt to determine the current status and distribution of the species showing abundantly invaded areas and main expansion routes. Due to limitations of time and human resources in performing the field survey, blank squares within the grid cannot be implicitly interpreted as absence; to some extent it might mean that species was not detected. Early herbarium and literature records lack assessment of abundance, thus they were excluded from the maps. Nevertheless, the maps presented in this paper can be used as basis for future studies and monitoring of the spread of both species.

In conclusion, similarly to many other European countries, in Latvia $S$. canadensis is one of the most aggressive plant invaders, rapidly spreading throughout the country and extending its distribution area, while $S$. gigantea still remains a rare invader most probably due to its confined introduction range; however, knowing its success in Central Europe it is perhaps a potentially widespread species that may reach the same invasiveness status as $S$. canadensis.

\section{ACKNOWLEDGEMENTS}

The research was supported by the European Social Fund. I am grateful to L. Engele and L. Grinberga for reporting the localities of species.

\section{REFERENCES}

Anonīms (2004). Pḷavu un lauksaimniecības zemju un sugu monitorings [Monitoring of grasslands and agricultural lands]. Rīga: Latvijas Dabas fonds, 30.-33. 1pp. (in Latvian).

Anonīms (2006). Dabas liegums "Krēmeri": dabas aizsardzības plāns [Nature Conservancy Area "Krēmeri": Plan for Nature Protection]. Rīga: Grupa 93, 26 lpp. (in Latvian).

Anonīms (2007). Dabas liegums "Ilgas": dabas aizsardzības plāns [Nature conservancy area "Ilgas": Nature protection plan]. Rīga: Estonian, Latvian and Lithuanian Environment. 31 lpp. (in Latvian).

Bickis, J., Rasiņš, A. (1946). Latvijas augu noteicējs [Key of Latvian Plants]. Rīga: Latvijas Valsts izdevniecība. 343 lpp. (in Latvian).

Cornelius, R. (1990). The strategies of Solidago canadensis L. in relation to urban habitats. III. Conformity to habitat dynamics. Acta Oecol., 11(3), 301-310.

Dancza, I., Botta-Dukát, Z. (2001). Historical and recent data on the distribution of North American Solidago species ( $S$. gigantea Ait. and $S$. canadensis L.) in Hungary. In Proceedings of the 6th International Conference Ecology and Management of Alien Plant Invasions, 12-15 September 2001, Loughborough University, UK. http://www.lboro.ac.uk/research/ cens/invasives/6emapi_oral_abs.htm [cited in 1 Nov 2007].

Forman, J. (2003). The introduction of American plant species into Europe: issues and consequences. In Child, L.E., Brock, J.H., Brundu, G., Prach, K., Pyšek, P., Wade, P.M., Williamson, M. (eds.). Plant Invasions: Ecolog- ical Threats and Management Solutions (pp. 17-39). Leiden: Backhuys Publishers.

Gassman, A., Weber, E. (2005). Solidago canadensis. In Wittenberg, R. (ed.). An Inventory of Alien Species and Their Threat to Biodiversity and Economy in Switzerland. CABI Bioscience Switzerland Centre report to the Swiss Agency for Environment, Forests and Landscape (pp. 413-414). Delemont.

Guzikowa, M., Maycock, P.F. (1986). The invasion and expansion of three North American species of goldenrod (Solidago canadensis L. sensu lato, S. gigantea Ait. S. graminifolia (L.) Salisb.) in Poland. Acta Soc. Bot. Polon., 55, 367-384.

Güsewell, S., Jakobs, G., Weber, E. (2006). Native and introduced populations of Solidago gigantea differ in shoot production but not in leaf traits or litter decomposition. Funct. Ecol., 20, 575-584.

Harnett, D.C., Bazzaz, F.A. (1983). Physiological integration among interclonal ramets in Solidago canadensis. Ecology, 64(4), 779-788.

Henderson, S., Dawson, T.P., Whittaker, R.J. (2006) Progress in invasive plants research. Progr. Phys. Geogr., 30(1), 25-46.

Hodkinson, D.J., Thompson, K. (1997). Plant dispersal: The role of man. $J$. Appl. Ecol., 34, 1484-1496.

Ieviņa, S. (1964). Ziemciešu puḳu asortimenta dinamika Latvijas PSR teritorijā laikā no 1805. līdz 1940. gadam [Dynamics of wintergreen assortment in the Latvian SSR in a period from 1805 to 1940]. In Daiḷārzniecība 5 (129.-146. 1pp). Rīga: Latvijas PSR Zinātṇu akadēmijas izdevniecība (in Latvian).

Jakobs, G., Weber, E., Edwards, P.J. (2004). Introduced plants of the invasive Solidago gigantea (Asteraceae) are larger and grow denser than conspecifics in the native range. Divers. Distrib., 10, 11-19.

Lacey, W.S. (1957). A comparison of the spread of Galinsoga parviflora and G. ciliata in Britain. In Lousley, J.E. (Ed.) Progress in the Study of the British Flora (pp. 109-115). London: Botanical Society of the British Isles.

Lohmeyer, W., Sukopp, H. (1992). Agriophyten in der Vegetation Mitteleuropas. Schriftenreihe für Vegetationskunde, 25, 1-185.

Mack, R.N. (2000). Assessing the extent, status and dynamism of plant invasions: Current and emerging approaches. In Mooney, H.A, Hobbs, R.J. (eds.). Invasive Species in a Changing World (pp. 141-168). Washington D.C.: Island Press.

Mandák, B., Pyðek, P., Bímová, K. (2004). History of the invasion and distribution of Reynoutria taxa in the Czech Republic: A hybrid spreading faster than its parents. Preslia (Prague) 76, 15-64.

Müller, N., Okuda, S. (1998). Invasion of alien plants in floodplains-a comparison of Europe and Japan. In Starfinger, U., Ewards, K., Kowarik, I., Williamson, M. (eds.) Plant Invasions: Ecological Mechanisms and Human Response (pp. 321-332). Leiden: Backhuys Publishers.

Pētersone, A. (1959). Kurvjziežu dzimta - Compositae (Vaill.) Adans. [Daisy family - Compositae (Vaill.) Adans.] In Galenieks, P. (ed.), Latvijas PSR flora. 4. sēj. (410-411. lpp.). Rīga: Latvijas Valsts izdevniecība, (in Latvian).

Pyšek, P., Prach, K. (1995). Invasion dynamics of Impatiens glandulifera-a century of spreading reconstructed. Biol. Conserv., 74, 41-18.

Pyšek, P., Sádlo, J., Mandák, B. (2002). Catalogue of alien plants of the Czech Republic. Preslia (Prague), 74, 97-186.

Tokarska-Guzik, B. (2003). The expansion of some alien plant species (neophytes) in Poland. In Child, L.E., Brock, J.H., Prach, K., Pyšek, P., Wade, P.M., Williamson, M. (eds.) Plant invasions: Ecological threats and management solutions (pp. 147-167). Leiden: Backhuys Publishers.

Walck, J.L., Baskin, J.M., Baskin, C.C. (1999). Relative competitive abilities and growth characteristics of a narrowly endemic and geographically widespread Solidago species (Asteraceae). Amer. J. Bot., 86(6), 820-828.

Weber, E. (1998). The dynamics of plant invasions: A case study of three exotic goldenrod species (Solidago L.) in Europe. J. Biogeogr., 25, 147-154. 
Weber, E. (2000). Biological flora of Central Europe: Solidago altissima L. Flora, 195, 123-134.

Weber, E. (2001). Current and potential ranges of three exotic goldenrods (Solidago) in Europe. Conserv. Biol., 15(1), 122-128.

Received 28 April 2008
Weber, E., Schmid, B. (1998). Latitudinal population differentiation in two species of Solidago (Asteraceae) introduced into Europe. Amer. J. Bot., 85(8), 1110-1121.

Weber, E., Jakobs, G. (2005). Biological flora of Central Europe: Solidago gigantea Aiton. Flora, 200, 109-118.

Табака, Л., Гаврилова, Г., Фатаре, И. (1988). Флора cocyдистых растений Латвийской ССР [Vascular flora of the Latvian SSR]. Рига, Зинатне, 194 с. (in Russian).

\section{INVAZĪVAS Solidago SUGAS LATVIJĀ: IZPLATĪBAS VĒSTURE UN IZPLATĪBA MŪSDIENĀS}

Ārpus izcelsmes areāla introducētās Ziemel̦amerikas zeltgalvīšu sugas introducētas un plaši pārgājušas savval̦ā lielākajā daḷā Eiropas. Kanādas zeltgalvīte Solidago canadensis ir gan lielākajā dạ̦ā Eiropas, gan Latvijā bieži sastopama invazīva augu suga, turpretī Centrāleiropā plaši izplatîtā milzu zeltgalvīte S. gigantea ir reta lielā daḷā Ziemeḷu un Austrumu Eiropas, ieskaitot Latviju. Šis pētījums pirmoreiz apkopo ziṇas par abu zeltgalvǐšu izplatību un dinamiku Latvijāa, rezultāti atspoguḷoti kartēs. Izplatības dati ievākti galvenokārt lauka pētījumos (2004-2007). Izmantoti arī herbāriju materiāli, literatūras un nepublicēti dati. Abas zeltgalvǐšu sugas pieder pie plašas ekoloğiskās amplitūdas sugām, tās visbiežāk sastopamas pārveidotos biotopos apdzīvotu vietu un ceḷu tuvumā. Abu sugu veiksmīgu izplatību pēdējā gadsimta laikā veicinājušas galvenokārt zemes lietojumveidu izmaiņas, antropogēnas ietekmes palielināšanās uz ekosistēmām un transporta tīklu attīstība. 